\title{
Társult tumorok előfordulása krónikus lymphoid leukaemiában
}

\author{
Szerafin László dr. - Jakó János dr. - Varju Lóránt dr. \\ Szabolcs-Szatmár-Bereg Megyei Jósa András Oktatókórház, Hematológiai Osztály, Nyíregyháza
}

\begin{abstract}
Bevezetés: A krónikus lymphoid leukaemia az egyik leggyakoribb hematológiai rosszindulatú kórkép. Célkitüzés: A 2000-2015 között diagnosztizált krónikus lymphoid leukaemiás betegek körében előfordult társuló rosszindulatú daganatok jellemzőinek vizsgálata. Módszer: A szerzők az adott időszakban kórismézett krónikus lymphoid leukaemiás betegek körében felismert további daganatban szenvedők adatait elemezték a Szabolcs-Szatmár-Bereg Megyei Leukaemia/Lymphoma Regiszter és a betegdokumentációk alapján. Eredmények: A 2000. január 1. és 2015. december 31. között diagnosztizált B-sejtes krónikus lymphoid leukaemiás betegek száma 526 volt. Ebből 95 betegben találtak társult egyéb tumort (18,06\%). 48/95 esetben (50,5\%) a krónikus lymphoid leukaemia volt az első́ként diagnosztizált tumor, 23/95 esetben $(24,2 \%)$ a társult daganatot diagnosztizálták elsőként, míg 24/95 esetben $(25,3 \%)$ a krónikus lymphoid leukaemia és a társult egyéb tumor szinkron megjelenésû volt. Többes társult tumort 10/95 betegben $(10,5 \%)$ találtak, az összes társult tumor száma 107 volt. A krónikus lymphoid leukaemia incidenciája 2000-2015 között jelentósen növekedett az 1983-1999 közötti időszakhoz képest (3,19/100 000 lakos/év vs. 5,65/100 000 lakos/év; 1,77-szoros növekedés). A társult tumoros betegségek előfordulásának gyakorisága szintén emelkedett (8,06\% vs. $18,06 \%)$. A leggyakrabban előforduló rosszindulatú daganatokon (colorectalis, emlő, hörgő, prostata) kívül gyakori volt a bőrlaphám-carcinoma (17/95 eset, 17,9\%) és a melanoma (6/95 eset, 6,3\%) társulása is. A krónikus lymphoid leukaemia diagnózisát követő́n és azzal szinkron megjelenő tumorok gyakoriak voltak (84/107 eset, az összes társult daganat 78,5\%-a). A szekunder daganatok incidenciája csak a krónikus lymphoid leukaemia diagnózisát követő tíz év után csökkent. Következtetések: A krónikus lymphoid leukaemiához társuló egyéb daganatok gyakoriságának és időbeli megjelenésének lehetséges okai a betegek magas életkora, a krónikus lymphoid leukaemia okozta immunszuppresszív állapot és feltehetően a krónikus lymphoid leukaemia kemoterápiája. A betegek gondozása során figyelni kell társuló daganatok kialakulásának lehetőségére. A betegek kezelését csak indokolt esetben kezdjük el. Orv. Hetil., 2016, 157(44), 1752-1756.
\end{abstract}

Kulcsszavak: krónikus lymphoid leukaemia, társuló/másodlagos daganatok, laphámcarcinoma

\section{Occurrence of associated tumours in chronic lymphocytic leukemia}

Introduction: Chronic lymphocytic leukemia is one of the most common hematologic malignancy. Aim: The aim of the authors was to investigate the characteristics of malignancies associated with chronic lymphocytic leukemia in patients diagnozed between 2000 and 2015. Method: Data of patients with chronic lymphocytic leukemia who had other associated tumours were analysed using the Leukemia/Lymphoma Registry of the Szabolcs-Szatmár-Bereg County, Hungary and patient records. Results: Between January 1, 2000 and December 31, 2015, 526 patients with chronic lymphocytic leukemia were diagnosed. 95 patients of the 526 patients $(18.06 \%)$ were diagnosed as having associated other tumours. In $48 / 95$ patients $(50.5 \%)$ the first diagnosed tumour was chronic lymphocytic leukemia, in $23 / 95$ patients $(24.2 \%)$ the first recognized malignancy was the associated tumour, whereas in $24 / 95$ patients (25.3\%) synchron tumours were diagnosed. The number of patients with more than one associated tumour was $10 / 95(10.5 \%)$. The total number of tumours was 107. The incidence of chronic lymphoid leukemia increased in the period between 2000 and 2015 as compared to the period between 1983 and 1999 (3.19 vs 5.65/100 000 person/ year). The occurrence of associated malignancies increased as well (8.06\% vs $18.06 \%)$. In addition to the most common tumours (colorectal, breast, lung, prostate), skin squamous cell carcinoma (17/95 patients; $17.9 \%)$ and melanoma $(6 / 95$ patients; $6.3 \%)$ also frequently occurred. The second malignancies were most frequently discovered after the diagnosis of chronic lymphocytic leukemia and synchron tumours accounting for $78.5 \%(84 / 107)$ of all associated tumours. The incidence of second malignancies decreased 10 years after the diagnosis of chronic lymphocytic leukemia. Conclusions: The possible reasons for the high frequency of other tumours associated with chronic lympho- 
cytic leukemia are elderly age of patients, immunsuppressed state and, presumably, chemotherapy of patients with chronic lymphocytic leukemia. During the follow up of patients the high risk for the development of associated tumours should be considered. Therapy of patients should be initiated when it is neccessary.

Keywords: chronic lymphocytic leukemia, associated/second malignancies, squamous cell carcinoma

Szerafin, L., Jakó, J., Varju, L. [Occurrence of associated tumours in chronic lymphocytic leukemia]. Orv. Hetil., 2016, 157(44), 1752-1756.

(Beérkezett: 2016. június 30.; elfogadva: 2016. augusztus 17.)

\section{Rövidítések}

$\mathrm{cc}=$ carcinoma CLL = krónikus lymphoid leukaemia

A krónikus lymphoid leukaemia (CLL) az egyik leggyakoribb hematológiai rosszindulatú kórkép, amely általában idősebb életkorban jelentkezik és többnyire indolens kórlefolyás jellemzi. Viszonylag gyakran fordul elő autoimmun betegségekkel és más daganatokkal együtt. Van den Broek és mtsai megfigyelése szerint korábbi szolid tumorok után a túlélők között a CLL kialakulásának kockázata 90\%-kal nagyobb, az első évben a rizikó több mint 4-szeres, bár a szinkron tumorok kizárása után a rizikó már nem volt nagyobb [1]. Régóta ismert, hogy a CLL a másodlagos malignomák fokozott rizikójával társul [2]. Davis és mtsai CLL-es betegei között 48/419 $(11,45 \%)$ arányban észleltek második rákos daganatot, köztük leggyakoribb a hörgőrák volt [3]. Bertoldero és mtsai 19/212 (8,96\%) betegükben figyeltek meg második daganatot, amelyek között szintén a hörgőrák dominált [4]. Hisada és mtsai 16376 beteg utánkövetése során 5\%-ukban találtak újabb daganatot (másodlagos hematológiai kórképeken kívül), a második tumor kialakulásának kockázatát a CLL diagnózisát követő egy éven belül és tíz éven túl hasonlónak találták [5]. Schöllkopf és mtsai 12373 CLL-es betegük sorsát követték nyomon, köztük 1105-ben (11,2\%) alakult ki szekunder malignoma, 10 év követés után is minden ráktípus megjelenése gyakoribb maradt [6]. Morton és mtsai a CLL-ben a hörgőrákot és melanomát találták a leggyakoribb daganatnak [7]. Több szerző is egybehangzóan a második tumorok közül a bőrlaphámrák kiemelkedő gyakoriságára hívja fel a figyelmet [8-14]. A CLL után kialakult laphám-cc kiújulásra hajlamosabb, agresszívebb kórlefolyású, magasabb halálozású a vártnál [12-14]. Az ilyen esetekben a CLL kórjóslata is rosszabb [14]. Jelen munkánkban 2000 és 2015 között diagnosztizált CLLes betegeink között előfordult társuló rosszindulatú daganatok (kivétel egyéb hematológiai kórképek és basaliomák) kórismézési idejének, típusainak, jellemzőinek vizsgálatát tűztük ki célul.

\section{Módszer}

A 2000. január 1. és 2015. december 31. közötti időszakban az osztályunkon diagnosztizált CLL-es betegek között a CLL diagnózisa előtt, után és azzal egy időben (szinkron tumorok: a különböző malignitások diagnózisa között eltelt idő a 6 hónapot nem haladja meg) felismert további daganatban szenvedők adatait elemeztük a Szabolcs-Szatmár-Bereg Megyei Leukaemia/Lymphoma Regiszter és a betegdokumentációk segítségével. A CLL, illetve a társult tumorok incidenciaadatait összehasonlítottuk a közel hasonló hosszúságú, 1983-1999 közti időszakban tapasztaltakkal. Szabolcs-Szatmár-Bereg megye népessége a vizsgált időszakokban 572 ezer fő volt. (A lakosságszám az évek során lényegesen nem változott.) A nyers incidencia értelmében a 100000 lakosra vonatkozó évenkénti új esetek számának átlagát adtuk meg. Vizsgáltuk a betegek életkorát a CLL diagnózisának időpontjában, a CLL és a társult tumor felismerése között eltelt időtartamot, a CLL-lel társult daganatok típusait, az alkalmazott kezeléseket. Az elemzésből kizártuk a CLL-lel társult egyéb malignus hematológiai kórképeket (egy diffúz nagy B-sejtes lymphoma, egy margináliszóna-lymphoma, egy polycythaemia vera és egy myeloma multiplex eset), valamint a basaliomákat. A CLL incidenciájának változását a vizsgált időszakok között és a CLL utáni második daganat életkor szerinti jelentkezésének szignifikanciáját $\chi^{2}$-próbával, a társult tumorok száma közötti különbséget a két megfigyelt időtartam között a relatív kockázat meghatározásával vizsgáltuk.

\section{Eredmények}

2000. január 1. és 2015. december 31. között osztályunkon 526 esetben diagnosztizáltunk B-sejtes CLL-t. Közöttük az egyéb tumorral társult CLL-es betegek száma 95 (18,06\%) volt. A betegek száma (526 vs. 310), a CLL incidenciája $(5,65$ vs. 3,19$)$ és a társult daganatok aránya (20,3 vs. 9,7\%) egyaránt jelentősen meghaladta az 1983-1999 közötti, közel hasonló hosszúságú időtartamban észlelt gyakoriságokat (1. táblázat). A betegek életkora 30-90 év, medián 70 év volt, köztük 60 éves vagy fiatalabb 21, 60 évnél idősebb 74 fö, a férfi:nő arány 53:42 (55,8\%-44,2\%). Többes társult daganatot 10/95 betegben $(10,5 \%)$ találtunk. Ezért az összes társult tumorok száma 107 volt. Időrendben elsőként a CLL-t diagnosztizáltuk 48 betegünknél $(50,5 \%)$, az egyéb társult daganatot 23 esetben $(24,2 \%)$, a szinkron felismert tumoros betegek száma $24(25,3 \%)$ volt (1.ábra). Nyolc 
1. táblázat

A CLL incidenciája és a társult daganatok gyakorisága 1983 1999 és 2000-2015 között

\begin{tabular}{lllll}
\hline $\begin{array}{l}\text { Vizsgált } \\
\text { időszak }\end{array}$ & Betegszám & Beteg/év & CLL-incidencia & $\begin{array}{l}\text { Társult } \\
\text { daganatok } \\
\text { száma }\end{array}$ \\
\hline $1983-1999$ & 310 & 18,2 & $\begin{array}{l}3,19 / 100000 \\
\text { lakos/év }\end{array}$ & $\begin{array}{l}30 / 310 \\
(9,7 \%)\end{array}$ \\
$2000-2015$ & 526 & 32,9 & $\begin{array}{l}5,65 / 100000 \\
\text { lakos/év }\end{array}$ & $\begin{array}{l}107 / 526 \\
(20,3 \%)\end{array}$ \\
\hline
\end{tabular}

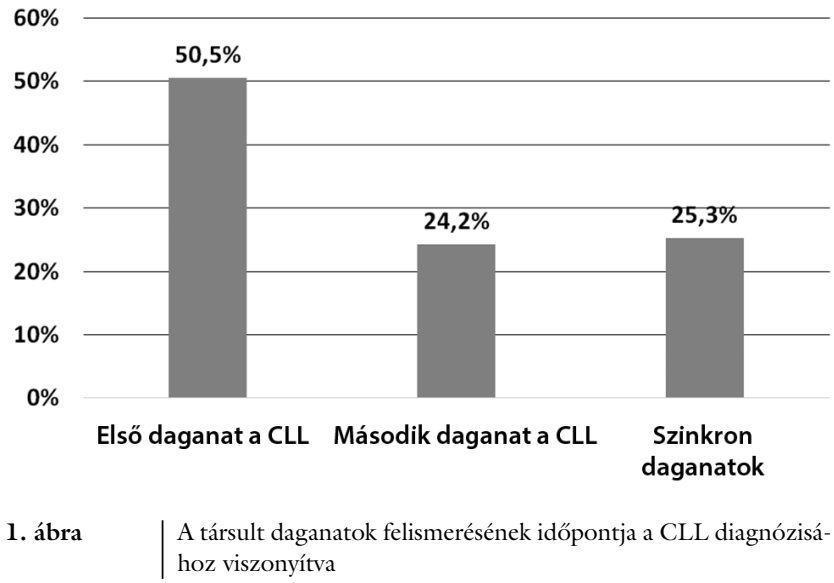

betegünkben ismertünk fel a CLL-en kívül két másik daganatot, ahol a második társult tumor 2-2 esetben colorectalis cc, bőrlaphám-cc, egy-egy betegben melanoma-, prostata-, endometrium-, illetve pajzsmirigy-cc volt. Két esetben három további malignomát diagnosztizáltunk, amelyekben a második és hamadik daganat melano$\mathrm{ma}+$ epitheloid bőrtumor, illetve rectum-cc + veseoncocythoma volt. A CLL-hez társult tumorok típusait részletesen a 2. táblázatban tüntettük fel. Ezek között a legtöbbször a leggyakoribb ráktípusok (colorectalis, hörgô, emlő, prostata) szerepelnek, feltünő azonban a bőrlaphám-cc gyakorisága, amely a második leggyakoribb társult tumornak bizonyult (17/107 társult daganat, az összes eset 15,9\%-a). Viszonylag sokszor találkoztunk melanoma malignummal is ( 6 eset). CLL-t követően a második daganat $(\mathrm{n}=48) 60$ éves kor alatt 12 betegben (az összes 60 év alatti beteg 57,1\%-ában [12/21]), 60 éves kor felett 36 esetben (az összes 60 év feletti beteg 48,6\%-ában [36/74]) alakult ki. A CLL dignózisa utáni tíz esztendőben a második daganatok viszonylag egyenletes gyakorisággal jelentek meg (0,5-5 év után 21, 6-10 év között 20 felismert tumor), számuk csak a 11. évtől csökkent jelentôsen (a CLL diagnózisa utáni 11-17. év között már csak 7 megbetegedés) (2.ábra). A CLL előtt jelentkező tumorok $(\mathrm{n}=23)$ közül 4 betegnél került sor kemoterápiára, 12 beteg $(52,2 \%)$ kapott sugárkezelést. Az első malignomaként diagnosztizált CLL $(\mathrm{n}=48) \mathrm{mi}$ att 31 beteg $(64,6 \%)$ kapott kemoterápiát, amely 30 esetben alkilálószert (is) tartalmazott (chlorambucil, cy-
2. táblázat | CLL-hez társult tumorok típusai

\begin{tabular}{|c|c|c|c|c|}
\hline $\begin{array}{l}\text { CLL-lel társult } \\
\text { daganat }\end{array}$ & Összes & $\begin{array}{l}\text { Diagnózis } \\
\text { CLL előtt }\end{array}$ & $\begin{array}{l}\text { Diagnózis } \\
\text { CLL után }\end{array}$ & $\begin{array}{l}\text { Diagnózis } \\
\text { szinkron }\end{array}$ \\
\hline Colorectalis & 23 & 5 & 12 & 6 \\
\hline Bőrlaphám-cc & 17 & 3 & 13 & 1 \\
\hline Hörgő & 13 & 2 & 6 & 5 \\
\hline Emlő & 12 & 6 & 4 & 2 \\
\hline Prostata & 10 & 2 & 5 & 3 \\
\hline Melanoma malignum & 6 & 1 & 4 & 1 \\
\hline Vese & 5 & 1 & 3 & 1 \\
\hline Húgyhólyag & 4 & 0 & 2 & 2 \\
\hline Petefészek & 2 & 0 & 2 & 0 \\
\hline Endometrium & 2 & 0 & 1 & 1 \\
\hline $\begin{array}{l}\text { Glioblastoma } \\
\text { multiforme }\end{array}$ & 2 & 0 & 1 & 1 \\
\hline Kaposi-sarcoma & 2 & 2 & 0 & 0 \\
\hline Máj & 1 & 0 & 1 & 0 \\
\hline Gyomor & 1 & 0 & 1 & 0 \\
\hline Hasnyálmirigy & 1 & 0 & 1 & 0 \\
\hline Here & 1 & 1 & 0 & 0 \\
\hline Penis & 1 & 0 & 1 & 0 \\
\hline Pajzsmirigy & 1 & 0 & 1 & 0 \\
\hline Agyburok & 1 & 0 & 1 & 0 \\
\hline Merkel-sejtes bőrrák & 1 & 0 & 0 & 1 \\
\hline $\begin{array}{l}\text { Bör epithelioid sejtes } \\
\text { angiosarcoma }\end{array}$ & 1 & 0 & 1 & 0 \\
\hline Összesen & 107 & 23 & 60 & 24 \\
\hline
\end{tabular}

clophosphamid). Többvonalbeli, kombinált gyógyszeres kezelést 11 esetben $(21,6 \%)$ alkalmaztunk (rituximab, fludarabin is). Egy beteg kapott alemtuzumabot.

\section{Megbeszélés}

Osztályunkon 2000 és 2015 között 526 betegnél diagnosztizáltunk B-sejtes CLL-t. Közülük 95 esetben $(18,06 \%)$ találtunk további daganatot a CLL megállapítása előtt, után vagy kevesebb mint hat hónap eltéréssel

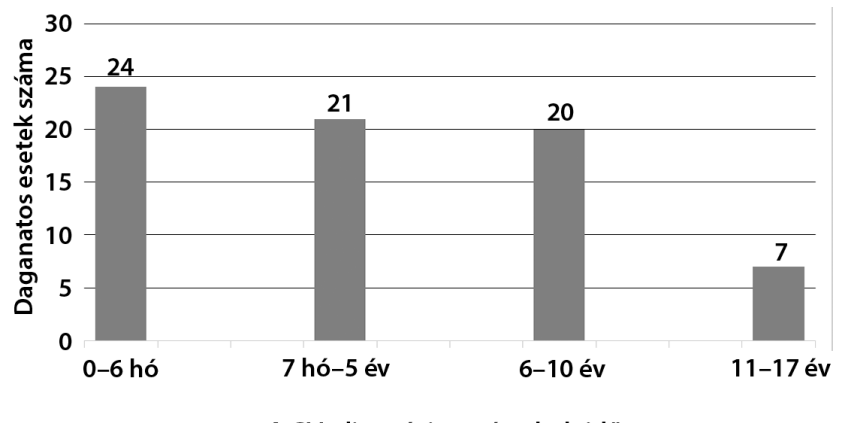

A CLL diagnózisa után eltelt idő

2. ábra A második daganat megjelenésének időpontja a CLL diagnózisát követően $(\mathrm{n}=48)$ 
(szinkron tumor). Betegeink körében a CLL incidenciája a vizsgált időszakban jelentősen emelkedett a korábbi, hasonló hosszúságú, 1983-1999 közötti időszakban észlelthez képest (CLL-incidencia: 5,65 vs. 3,19; p<0,000, társult daganatok aránya: $20,3 \%$ vs. 9,7\%, RR: 2,80 [CI 95\%: 0,34-5,25]). Ennek hátterében az utóbbi időben gyakoribb orvoshoz fordulások, rutin-vérképvizsgálatok miatt sok, korai stádiumban felismert CLL és ezeknek a betegeknek a szorosabb követése, orvosi ellenőrzése állhat, de valódi incidencianövekedés sem zárható ki. Ismert, hogy a CLL a másodlagos malignomák fokozott rizikójával társul [2]. A CLL előtt jelentkező malignus folyamatot saját betegeink között csak 24,2\%-ban (23/95 eset) diagnosztizáltunk. Van den Broek és mtsai ugyan korábbi primer tumor megjelenése után a CLL rizikóját 90\%-kal nagyobbnak találták, de a szinkron tumorok kizárása után ez a rizikó már nem bizonyult nagyobbnak [1]. Ugyanakkor több szerző a CLL utáni szekunder neoplasmák gyakoriságának jelentős emelkedéséről számolt be [2-8], amelyek között a leggyakoribb rákfajtákon (colorectalis, hörgő-, emlő-, prostata-cc) kívül szokatlanul magas arányban fordultak elő bőrlaphám-cc-k és részben melanomák $[1,7,9,10,12-14]$, s ezek prognózisa is az átlagosnál kedvezőtlenebb. Saját beteganyagunkban szintén az esetek felében $(50,5 \%)$ a CLL volt az első felismert rosszindulatú kórkép, és a szinkron előfordulás is gyakori $(25,3 \%)$ volt. A CLL diagnózisát követően és azzal szinkron megjelenő tumor az összes daganat 78,5\%-át $(60+24=84 / 107$ daganat $)$ tette ki. A daganatstatisztikákat vezető colorectalis, hörgő-, emlö- és prostatadaganatokkal találkoztunk mi is a leggyakrabban, és - az irodalomban közöltekkel összhangban - a második leggyakoribb társult daganat a bőrlaphám cc-je (17 eset) volt, de a melanoma malignum is a sorrendben a hatodik helyen (6 eset) áll. A CLL-hez társuló egyéb daganatok gyakoriságának és időbeli megjelenésének hátterében több lehetséges ok merül fel. A betegek többnyire magas életkora (vizsgálatunkban a medián életkor 70 év). Az életkor előrehaladtával gyakoribb a rosszindulatú daganatok kialakulása. A többnyire lassú kórlefolyású CLL-lel együtt járó immundeficiens állapot hajlamosíthat további daganatok kialakulására. A napsugárzás (elsősorban bőrdaganatok esetében) és a dohányzás előbbieket fokozó hatása jogosan feltételezhető. A CLL-es betegek fokozott orvosi ellenőrzés alatt állnak, ezért további daganatok (korai) felismerésének is nagyobb az esélye [8]. Flynn és mtsai a humán papillomavírus lehetséges szerepét vetették fel a CLL utáni szekunder neoplasiák kialakulásában [9]. A 132 CLL-es beteg 44 második neoplasmájának mintáját vetették össze random módon illesztett 264 kontrollegyén 54 daganatával. Előbbiek között 53\%-ban, míg utóbbiak mintájában egyetlen esetben sem tudtak polimeráz láncreakcióval humán papillomavírust kimutatni. Magunk humán papillomavírus-kimutatást betegeinkben nem végeztünk.
A CLL-hez társult daganatok okainak vizsgálata során nem hagyható figyelmen kívül a kezelésben alkalmazott gyógyszerek karcinogén szerepe sem. A CLL-t megelőző szolid tumor kevésbé gyakori (betegeink között 23/95 fó, 24,2\%), s bár ezek 52,2\%-a kapott lokális sugárkezelést, kemoterápiában csak 17,4\%-uk részesült. Azonban föleg a CLL-t követő második daganatok esetében a CLL gyógyszeres kezelése nem hagyható figyelmen kívül $[8,15]$. Saját szekunder tumoros CLL-es betegeink 64,6\%-a (31/48 fó) kapott kemoterápiát, amely a legtöbb esetben (30) alkilálószert (is) tartalmazott, 21,6\%-uk (11/48 fó) többvonalbeli, illetve kombinált kezelésben részesült (utóbbiak rituximabot és fludarabint is tartalmaztak). A CLL kemoterápiájának további daganatot okozó esetleges hatását több tanulmány vizsgálta, de ez ma még nem egyértelmúen megválaszolható kérdés [15]. Callea és mtsai nem találtak különbséget a másodlagos neoplasiák gyakoriságában a nem kezelt, illetve az indukciós + fenntartó chlorambucilkezelésben részesült CLL-es betegek között, és a kezelés időtartama sem okozott különbséget. Viszont a chlorambucil után fludarabin + cyclophosphamid kombinációval kezelt betegek 30,8\%-ában myelodysplasia alakult ki. Ezenkívül szignifikánsan gyakoribbnak találták a második daganat kialakulását a korai Binet $\mathrm{A}$, mint a Binet $\mathrm{B}$ és $\mathrm{C}$ stádiumú betegekben [16]. Vidal és mtsai szerint az önmagában adott chlorambucil nem fokozta a szekunder malignomák kockázatát [17]. Ugyanakkor Morrison és mtsai megfigyelése szerint chlorambucil és fludarabin kombinációja fokozhatja a terápiával összefüggő myeloid leukaemiák kialakulását (szolid tumorok vonatkozásában hasonlót nem írtak le) [18]. A közelmúltban Fischer és $m t s a i$ közölték a fludarabin + cyclophosphamid + rituximab kemoimmunoterápiás kombináció hosszú távú remissziót eredményező és a mutált IgVH-jú betegekben a túlélést javító hatását, viszont az így kezeltek 17,4\%ában, a fludarabin + cyclophosphamid kombinációval kezeltek 13,1\%-ában észlelték második malignoma kialakulását (beleértve a Richter-szindrómát is) [19]. Benjamini és mtsai fludarabin + cyclophosphamid + rituximab terápia után az átlagpopulációhoz képest a második tumorok kialakulásának 2,38-szoros kockázatát észlelték, amelyek többsége akut myeloid leukaemia/myelodysplasiás szindróma $(5,1 \%)$ és Richter-szindróma $(9 \%)$ volt [20]. Ezek az adatok a fludarabin és rituximab vonatkozásában megfontolásra intenek. Ugyanakkor a szolid daganatok sugárkezelése nem növeli a később kialakuló CLL kockázatát [21].

A CLL után előforduló második daganat 60 évnél fiatalabbak közötti előfordulását vizsgálatunkban kissé gyakoribbnak tapasztaltuk $(57,1 \%$ vs. $48,6 \%)$, de a különbség $\chi^{2}$-próbával nem bizonyult szignifikánsnak ( $\mathrm{p}=$ 0,70), ami hasonló van den Broek és mtsai észleléséhez [1]. Hisada és mtsai a szekunder neoplasiák kialakulásának kockázatát a CLL diagnózisát követő egy éven belül és tíz éven túl is hasonlónak találták [5], mi azonban tíz év elteltét követően határozott csökkenést tapasztaltunk 
(2. ábra). Ennek magyarázatául szolgálhat a betegek magas medián életkora. Az idő előrehaladtával a természetes halálozás miatt az újabb daganatok kialakulásának reális gyakorisága már nem ítélhető meg. Nemzetközi irodalmi adatok és saját adataink alapján is a CLL-es betegek gondozása során figyelni kell a társuló egyéb daganatok kialakulásának lehetőségére. A CLL-es betegek kezelését csak indokolt esetben kezdjük el.

Anyagi támogatás: A közlemény megírása, illetve a kapcsolódó kutatómunka anyagi támogatásban nem részesült.

Szerzői munkamegosztás: Sz. L.: Témaválasztás, a vizsgálat megtervezése, adatgyüjtés és -feldolgozás, a kézirat megírása, az irodalom összeállítása. J. J.: Adatgyưjtés, a kézirat megírása. V. L.: Adatgyújtés és -feldolgozás. A cikk végleges változatát mindhárom szerző elolvasta és jóváhagyta.

\section{Érdekeltségek: A szerzőknek nincsenek érdekeltségeik.}

\section{Irodalom}

[1] van den Broek, E. C., Liu, L., Posthuma, E. F., et al.: Increased risk of chronic lymphocytic leukaemia among cancer survivors in the Netherlands: increased detection, casual factors or both? Ann. Hematol., 2014, 93(1), 157-162.

[2] Wiernik, P. H.: Second neoplasms in patients with chronic lymphocytic leukemia. Curr. Treat. Options Oncol., 2004, 5(3), 215-223.

[3] Davis, J. W., Weiss, N. S., Armstrong, B. K.: Second cancers in patients with chronic lymphocytic leukemia. J. Natl. Cancer Inst., 1987, 78(1), 91-93.

[4] Bertoldero, G., Scribano, G., Podda, L., et al.: Occurrence of second neoplasms in chronic lymphocytic leukemia. Experience at Padua Hospital between 1979 and 1991. Ann. Hematol., 1994, 69(4), 195-198.

[5] Hisada, M., Biggar, R. J., Greene, M. H., et al.: Solid tumors after chronic lymphocytic leukemia. Blood, 2001, 98(6), 1979-1981.

[6] Schöllkopf, C., Rosendabl, D., Rostgaard, K., et al.: Risk of second cancer after chronic lymphocytic leukemia. Int. J. Cancer, 2007, $121(1), 151-156$.

[7] Morton, L. M., Curtis, R. E., Linet, M. S., et al.: Second malig nancy risks after non-Hodgkin's lymphoma and chronic lymphocytic leukemia: differences by lymphoma subtype. J. Clin. Oncol., 2010, 28(33), 4935-4944.

[8] Trawis, L. B.: Cancer survivorship: understanding risk. ASCO Educational Book, 2006, 520-523.

[9] Flynn, J. M., Andritsos, L., Lucas, D., et al.: Second malignancies in B-cell chronic lymphocytic leukaemia: possible association with human papilloma virus. Br. J. Haematol., 2010, 149(3), 388-390.

[10] Levi, F., Randimbison, L., Te, V. C., et al.: Non-Hodgkin's lymphomas, chronic lymphocytic leukaemias and skin cancers. Br. J. Cancer, 1996, 74(11), 1847-1850.

[11] Brewer, J. D., Shanafelt, T. D., Khezri, F., et al.: Increased incidence and recurrence rates of nonmelanoma skin cancer in patients with non-Hodgkin lymphoma: a Rochester Epidemiology Project population-based study in Minnesota. J. Am. Acad. Dermatol., 2015, 72(2), 302-309.

[12] Hartley, B. E., Searle, A. E., Breach, N. M., et al.: Agressive cutaneous squamous cell carcinoma of the head and neck in patients with chronic lymphocytic leukaemia. J. Laryngol. Otol., 1996, $110(7), 694-695$.

[13] Tomaszewski, J. M., Gavriel, H., Link, E., et al.: Agressive behavior of cutaneous squamous cell carcinoma in patients with chronic lymphocytic leukemia. Laryngoscope, 2014, 124(9), 20432048.

[14] Velez, N. F., Karia, P. S., Vartanov, A. R., et al.: Association of advanced leukemic stage and skin cancer tumor stage with poor skin cancer outcomes in patients with chronic lymphocytic leukemia. JAMA Dermatol., 2014, 150(3), 280-287.

[15] Molica, S.: Second neoplasms in chronic lymphocytic leukemia: incidence and pathogenesis with emphasis on the role of different therapies. Leuk. Lymphoma, 2005, 46(1), 49-54.

[16] Callea, V., Brugiatelli, M., Stelitano, C., et al.: Incidence of second neoplasia in patients with B-cell chronic lymphocytic leukemia treated with chlorambucil maintenance chemotherapy. Leuk. Lymphoma, 2006, 47(11), 2314-2320.

[17] Vidal, L., Gurion, R., Ram, R., et al.: Chlorambucil for the treatment of patients with chronic lymphocytic leukemia (CLL) - a systematic review and meta-analysis of randomized trials. Leuk. Lymphoma, 2016, 57(9), 2047-2057.

[18] Morrison, V. A., Rai, K. R., Peterson, B. L., et al.: Therapy-related myeloid leukemias are observed in patients with chronic lymphocytic leukemia after treatment with fludarabine and chlorambucil: results of an Intergroup Study, Cancer and Leukemia Group B 9011. J. Clin. Oncol., 2002, 20(18), 3878-3884.

[19] Fischer, K., Bablo, J., Fink, A. M., et al.: Long-term remissions after FCR chemoimmunotherapy in previously untreated patients with CLL: updated results of the CLL8 trial. Blood, 2016, $127(2), 208-215$.

[20] Benjamini, O., Jain, P., Trinh, L., et al.: Second cancers in patients with chronic lymphocytic leukemia who received frontline fludarabine, cyclophosphamide and rituximab therapy: distribution and clinical outcomes. Leuk. Lymphoma, 2015, 56(6), 1643-1650.

[21] Radivoyevitch, T., Sachs, R. K., Gale, R. P., et al.: Ionizing radiation exposures in treatments of solid neoplasms are not associated with subsequent increased risks of chronic lymphocytic leukemia. Leuk. Res., 2016, 43(3), 9-12.

(Szerafin László dr., Nyíregyháza, Szent István u. 68., 4400 e-mail: szerafin@josa.hu) 